\title{
An Investigation between Multiple Intelligences and Learning Styles*
}

\author{
Sabriye Şener ${ }^{1}$, Ayten Çokçalışkan ${ }^{2}$ \\ ${ }^{1}$ Foreign Language Education Department, Muğla Sitkı Koçman University, Turkey \\ ${ }^{2}$ National Ministry of Education, Turkey \\ Correspondence: Ayten Çokçalışkan, National Ministry of Education, Turkey.
}

Received: November 27, 2017

Accepted: January 14, $2018 \quad$ Online Published: January 27, 2018

doi:10.11114/jets.v6i2.2643

URL: https://doi.org/10.11114/jets.v6i2.2643

\begin{abstract}
Exploring learning style and multiple intelligence type of learners can enable the students to identify their strengths and weaknesses and learn from them. It is also very important for teachers to understand their learners' learning styles and multiple intelligences since they can carefully identify their goals and design activities that can teach to the different intelligences, and design student-centered activities. This study aims to reveal secondary school students' multiple intelligences and learning styles. It also aims to describe gender differences and the relationship between learning styles and multiple intelligences of the students. The research study employed a quantitative research design and the data were collected from the students of a state school in the winter term of 2015-2016 Education Year. The data were gathered by means of the two instruments: The Perceptual Learning-Style Preference Questionnaire (PLSPQ), and the Multiple Intelligence Inventory. It was observed that the students had almost all these types of learning styles but mostly they were found to be tactile and auditory learners. The three intelligence groups: Naturalistic, Visual and Kinesthetic intelligences types received the highest score. The analyses also indicated that there was a significant difference between males and females. It was seen that most of the intelligence types and learning styles had a moderate positive correlation.
\end{abstract}

Keywords: intelligences, gender, secondary school students, visual learners

\section{Introduction}

The Theory of Multiple Intelligences suggested by Gardner in the early 1980s as an alternative way to traditional classroom designs that as a need for the variety of ways people learn and understand. Gardner (1983) suggested that learners do not have a single intelligence, but a range of intelligences. His assumption is that all people have these intelligences but in each person one of them is more pronounced.

This new view on intelligence differs from the traditional view that usually recognizes only two intelligences. Gardner made a significant contribution to cognitive science by Multiple Intelligences Theory, which builds a learner-based philosophy. With the help of this theory, people can comprehend better how individual differences can be understood, approached and improved in a teaching and learning environment.

While identifying potentials of intelligences, various criteria should be taken into consideration. Gardner (1983, pp. 62-69) defined eight criteria to be identified as intelligence:

1. potential isolation by brain damage

2. the existence of idiots, savants, prodigies and other exceptional individuals

3. an identifiable core operation or set of operations

4. a distinctive developmental history

5. an evolutionary history and evolutionary plausibility

6. support from experimental psychological tasks

7. support from psychometric findings

8. susceptibility to encoding in a symbol system

${ }^{*}$ This paper was partly presented as an oral presentation at $3^{\text {rd }}$ International Eurasian Educational Research Congress

(EJER 2016) held in Muğla Sttkı Koçman University, Muğla-Turkey on May, 31-June 3, 2016. 
He described nine different intelligences based on the above criteria: logical - mathematical (number smart), verbal-linguistic (word smart), bodily-kinesthetic (body smart), musical-rhythmic (music smart), interpersonal (people smart), visual-spatial (picture smart), intrapersonal (self-smart), the naturalist (nature smart), existential. Each intelligence type is described below:

1. Verbal - linguistic Intelligence: Gardner (1993) explained this intelligence as sensitivity to the written and spoken language. This intelligence is mainly concerned with the ability to comprehend and compose language efficaciously both orally and in writing. Poets, writers, linguists, journalists, language teachers, etc. are the example of people who have the verbal-linguistic intelligence.

2. Logical/mathematical intelligence: This intelligence is the ability to calculate and comprehend situations or conditions systematically and logically. Students who have this type of intelligence are good at exploring patterns and relationships, problem solving, and reasoning (Gardner, 1999). This intelligence type can be connected with deductive reasoning. People who work in the scientific and mathematical fields are supposed to have this type of intelligence.

3. Visual/Spatial intelligence: This type of intelligence is described as the ability of perceiving, modifying and creating images. Artists, designers, architects, sculptors have highly this type of intelligence.

4. Musical intelligence: This type of intelligence is the ability to identify pitch, rhythm, and emotional side of sound. It is exemplified by musicians, singers, composers, and people who are interested in music.

5. Bodily/kinesthetic intelligence: This type of intelligence refers to use the body for expression. It is also described as the potential of using the body and its parts in mastering problems or creation of products. Athletes, professional dancers, mechanics, physical education instructors are in this group.

6. Intrapersonal intelligence: This intelligence requires the ability to have self-knowledge and recognize people's similarities and differences among them. Gardner (1999) adds that it involves the ability to understand yourself, and to interpret and appreciate your own feelings, emotions, desires, strengths, and motivations.

7. Interpersonal intelligence: This intelligence suggests the ability to identify, comprehend and appreciate the emotions, intentions, motivations, desires, and beliefs of other people. Teachers, therapists, salespersons, political leaders have high interpersonal intelligence. In Teele's (2000) view, interpersonal intelligent people are friendly and participate in social activities. These people prefer cooperative learning, exchanging information, and studying in groups.

8. Naturalistic intelligence: This type of intelligence is the ability to identify and classify the natural world around people. Teele (2000) states that these people live in harmony with the nature. Some occupations need a well-developed form of this intelligence, like astronomers, biologists, and zoologists. Gardner added this intelligence as the eighth one, after the first publication of the model.

9. Existential intelligence: This intelligence suggests the ability to question about the existence of human, death, the meaning of life and the reason for existence (Armstrong, 2009). It was added the list in 1999 by Gardner.

Language teachers are expected to consider multiple intelligences types of learners and plan, design activities from which all types of learners can benefit. If teachers understand there are different intelligences types in their classes, they can effectively carry out their lessons involving in all students, not just those who read and write or calculate well.

When it comes to the learning style, it is described by MacKeracher (2004, pp.71) as "the characteristic of cognitive, affective, social, and physiological behaviors that serve as relatively stable indicators of how learners perceive, interact with, and respond to the learning environment". Brown (2000) explains learning styles as the way in which people comprehend and process information in learning situations. He mainly identifies six main learning styles; visual learning, auditory learning, kinesthetic learning, tactile learning, group learning, and individual learning: the characteristic of different learner types are listed below:

1. Visual learners: Visual learners learn best in images. They are careful about teachers' body language, and are able to understand the situations, or conditions. They prefer sitting in front of the class.

2. Auditory learners: Auditory learners prefer processing information through listening and interpreting via pitch, emphasis, and speed. These learners favour reading aloud in the classroom.

3. Kinaesthetic learners: These individuals discover information through active "hands-on" approach. They gain knowledge from interaction with the physical world. They have difficulty in focusing on the situation.

4. Tactile learners: This type of learners learn best by using their hands. They prefer touching things to learn about them. They often underline what they read, take notes during listening, and keep their hands busy in 
other ways.

5. Individual learners: When people like their privacy and are independent, and introspective, they are probably individual learners. Learners with individual preference often can focus on the issues well, be aware of their own thinking, and analyze in a different way what they think and feel.

6. Group learners: These individuals are good at communicating well with people, both verbally and non-verbally. They prefer mentoring and counseling others.

A number of researchers have investigated the relationship between learning styles and multiple intelligences and their role in second and foreign language learning and many researchers have also worked on the role of individuals' learning styles in foreign language learning.

Identifying each person's learning styles and multiple intelligence types are crucial. For the students, being aware of their learning style and multiple intelligences types may be very beneficial and useful. Exploring this learning style and multiple intelligence type will allow them to identify their personal strengths and weaknesses and learn from them.

Tekiner (2005) searched the relationship between multiple intelligences and perceptual and social learning styles of university students in the Turkish context. It was found that there were positive relations between logical-mathematical intelligence and individual learning style; intrapersonal intelligence and individual learning style; interpersonal intelligence and group learning style; linguistic intelligence and individual learning style; and interpersonal intelligence and kinesthetic learning style. Sarıcaoğlu and Arıkan (2009) also carried out a research study with university students. They found that learners' preference for logical-mathematical intelligence was stronger. In the Iranian context, there are some similar research studies. Ahanbor and Sadighi (2014) investigated if a combination of learning styles and multiple intelligences would enhance students' learning or not. The results showed that all participants had linguistic, logical-mathematical, spatial, bodily-kinesthetic, musical, interpersonal, intrapersonal as well as naturalistic intelligences. A statistically significant relationship between learning styles and multiple intelligences was also determined. Similarly, in the Iranian context, Panahandeh et al. (2015) conducted a study to identify the relationship between EFL learners' multiple intelligences and their learning styles. They also focused on the most and the least dominant learning styles and investigated the difference between genders. As a result, only a significant difference was found between genders.

Luengo-Carvara (2015) examined learning styles and multiple intelligences as variables in the teaching-learning process of Spanish as a foreign language. Three moderate correlations had been found among the variables of both constructs: linguistic intelligence-reflexive style; linguistic intelligence-theoretical style; and musical intelligence-active style. As a result, students with a high preference for the reflective and theoretical style demonstrated a better overall performance.

In another context, Ali and Rajalakshmi (2016) conducted a research study with parents. They tried to find out the significance of parents' awareness of their child's multiple intelligences and learning styles. They stated that if parents were sensitive to use the Multiple Intelligence theory in children's education, then learning could be enjoyable, meaningful and thus the outcomes would be positive for both children and their parents. Hsu and Chen (2016) explored the relationship between tertiary level EFL college students' learning styles, and learning strategies. As a result, most of participants were balanced-type of learners on all learning style dimensions.

Apart from the studies presented above, Tsai (2016) investigated the differences of multiple intelligences according to some variables such as gender, grade, and students' types in junior school context. Results showed that depending on the average scores of multiple intelligences, seventh grade students got the highest scores on interpersonal intelligence, and got the lowest scores on natural intelligences, and general students and special needs students got the highest scores on interpersonal intelligence.

As it was given above, both in the Turkish context and other contexts the phenomena have been studied but in the Turkish context regarding secondary school students and investigating the relationship between multiple intelligences, learning styles and gender, there is limited number of research studies. The aim of this study is to examine the relationship between learners' learning styles and multiple intelligence types and gender in order to increase learners' language learning in the foreign language context. It is hoped that it will provide contribution to the field. To reach this goal, this study seeks to find answers to the following question:

RQ 1: What are the most preferred learning styles of the participants? Are there any gender differences?

RQ 2: What are the most preferred types of multiple intelligences of the participants? Are there any gender differences?

RQ 3: What is the relationship between students' types of multiple intelligences and learning styles? 


\section{Method}

\subsection{Research Design}

The research study employed a quantitative research design. Quantitative research is a scientific method which is closely associated with numerical values and statistics (Dörnyei, 2007). In quantitative research design the aim is to classify features, count them and construct statistical models in an attempt to explain what is observed. Quantitative data is more efficient to measure and analyze target concepts. The survey method was taken up as the main methodology, which is one of the most common methods of collecting data on attitudes and opinions from a relatively large number of participants. As Mackey and Gass (2005) pointed out questionnaires allow researchers to gather information that learners are able to express themselves.

\subsection{Research Sample}

The data were collected from the students of a state school in the winter term of 2015-2016 Education Year. The participants included 88 secondary school students of $5^{\text {th }}, 6^{\text {th }} 7^{\text {th }}$, and $8^{\text {th }}$ grades. They were 45 females and 43 males, between the ages of 11 and 14 with an average of 12. All of the students were native speakers of Turkish, and they learned English as a foreign language. In this study, non-random sampling procedure was benefitted to determine the participants to be investigated.

Table 1. Demographic characteristics of the participants

\begin{tabular}{llll}
\hline Variables & Categories & $\mathbf{N}$ & $\mathbf{\%}$ \\
\hline Gender & 1. Female & 45 & 51.1 \\
& 2. Male & 43 & 48.9 \\
\hline Grade & 1. Fifth Grade & 16 & 18.18 \\
& 2. Sixth Grade & 27 & 30.68 \\
& 3. Seventh Grade & 28 & 31.81 \\
& 4. Eighth Grade & 17 & 19.31 \\
\hline
\end{tabular}

\subsection{Research Instrument and Procedure}

The data were gathered by means of the two instruments. Firstly, the Perceptual Learning-Style Preference Questionnaire (PLSPQ) was used to identify the participants' perceptual learning style preferences. It was designed by Reid in 1995. There were two parts in the questionnaire. The first part included some questions to reveal the participants' demographic structure. The second part included the two scales. The Perceptual Learning-Style Preference Questionnaire (PLSPQ) included 30 learning strategy statements with 6 sub-categories each of which included 5 statements: Auditory Learning, Visual Learning, Tactile Learning, Kinesthetic Learning, Group Learning, and Individual Learning. It had high reliability (Cronbach's Alpha= 0.96). Turkish version of the same scale was provided from Tomakin (2012), who used the same scale in the Turkish context.

Secondly, the Multiple Intelligence Inventory designed by Armstrong (2000) was employed to determine the intelligence types of the participants. The 5-Likert scale included 80 items, which consisted of 8 subscales with 10 items in each category. All participants were handed out the data collection instruments in their regular class hour and it took them to complete approximately 80 minutes (2 lesson hours).

\subsection{Data Analysis}

The data gathered from the students were analysed by using the Statistical Package for the Social Sciences 20 (SPSS 20). From the parametric tests, independent sample t-tests and Pearson correlation coefficients and descriptive statistics were employed. Firstly, the reliability of each scale was tested. The Perceptual Learning-Style Preference Questionnaire (PLSPQ) was analysed and Cronbach's Alpha reliability was found 0.74. As for the second scale, the Multiple Intelligence Inventory, to check the reliability, Cronbach's Alpha was found 0.92.The Cronbach's alpha scores indicated that the scales used for the present study were highly reliable.

\section{Results}

Firstly, learning styles of the students were determined. It was observed that the students had almost all these types of learning styles. Mostly they were found to be tactile and auditory learners. The results can be seen in Table 2 . 
Table 2. Learning styles of the students

\begin{tabular}{llrrrc}
\hline Descriptive Statistics & \multicolumn{5}{c}{} \\
\hline & $\mathrm{N}$ & Minimum & Maximum & Mean & Std. Deviation \\
\hline Visual & 88 & 2.00 & 5.00 & 3.7159 & .78709 \\
Tactile & 88 & 2.00 & 5.00 & 3.8750 & .86851 \\
Auditory & 88 & 2.00 & 5.00 & 4.0455 & .75672 \\
Group & 88 & 1.00 & 5.00 & 3.4659 & 1.08224 \\
Kinesthetic & 88 & 2.00 & 5.00 & 3.6023 & .95339 \\
Individual & 88 & 1.00 & 5.00 & 2.9659 & 1.21720 \\
Valid N (list wise) & 88 & & & & \\
\hline
\end{tabular}

Secondly, the learning styles and gender differences were determined and it was found that male and female students enjoy from varying types of learning styles by varying degrees. In both of the learning style groups, female students outnumbered male students. Tactile, Auditory, and Kinaesthetic learning types of the females' have higher mean scores than males'.

Table 3. Learning styles of the students according to gender

\begin{tabular}{llllcccl}
\hline Learning Style & Gender & $\mathbf{N}$ & Mean & SD & t & df & p \\
\hline \multirow{2}{*}{ Visual } & Female & 45 & 3.8222 & .74739 & 1.301 & 86 & .197 \\
\multirow{2}{*}{ Tactile } & Male & 43 & 3.6047 & .82056 & 1.299 & 84.372 & $\mathrm{p}>0.05$ \\
& Female & 45 & 4.2222 & .73512 & 4.185 & 86 & .000 \\
Auditory & Male & 43 & 3.5116 & .85557 & 4.170 & 82.818 & $\mathrm{P}<0.05$ \\
& Female & 45 & 4.1556 & .73718 & 1.404 & 86 & .164 \\
Group & Male & 43 & 3.9302 & .76828 & 1.403 & 85.350 & $\mathrm{p}>0.05$ \\
& Female & 45 & 3.4000 & 1.07450 & -.582 & 86 & .562 \\
Kinesthetic & Male & 43 & 3.5349 & 1.09868 & -.582 & 85.602 & $\mathrm{p}>0.05$ \\
\multirow{4}{*}{ Individual } & Female & 45 & 3.8000 & .99087 & 2.025 & 86 & .046 \\
& Male & 43 & 3.3953 & .87667 & 2.031 & 85.504 & $\mathrm{P}<0.05$ \\
& Female & 45 & 2.7556 & 1.31694 & -1.676 & 86 & .097 \\
& Male & 43 & 3.1860 & 1.07473 & -1.683 & 83.973 & $\mathrm{p}>0.05$ \\
\hline
\end{tabular}

As for the second research question, most preferred types of multiple intelligence of the participants were analyzed. When the multiple intelligences types of the participants were examined, between groups a significant difference was not observed.

Table 4. Multiple intelligences types of the students

\begin{tabular}{llcccc}
\hline Descriptive Statistics & \multicolumn{7}{c}{} \\
\hline & $\mathrm{N}$ & Minimum & Maximum & Mean & Std. Deviation \\
\hline Total Verbal Intelligence & 88 & 1.00 & 5.00 & 3.7159 & .84349 \\
Total Logical Intelligence & 88 & 1.00 & 5.00 & 3.8068 & .89517 \\
Total Visual Intelligence & 88 & 2.00 & 5.00 & 4.0341 & .79436 \\
Total Musical Intelligence & 88 & 2.00 & 5.00 & 3.8864 & .80846 \\
Total Kinaesthetic Intelligence & 88 & 2.00 & 5.00 & 3.9205 & .80546 \\
Total Interpersonal Intelligence & 88 & 1.00 & 5.00 & 3.7045 & .84635 \\
Total Intrapersonal Intelligence & 88 & 2.00 & 5.00 & 3.7159 & .77235 \\
Total Naturalistic Intelligence & 88 & 2.00 & 5.00 & 4.0000 & .95893 \\
Valid N (list wise) & 88 & & & &
\end{tabular}

The difference between multiple intelligences types of students and gender was also examined. The result of descriptive statistics did not indicate any significant difference between male and female participants (See Table 5).

When multiple intelligences types of the students were calculated, it was observed that naturalistic intelligence had the highest mean score (See Table 5). The three intelligence groups, Naturalistic, Visual and Kinesthetic intelligences types, received the highest score.

The main objective of this study was to determine the relationship between students' learning styles and their types of multiple intelligences. It was revealed that most of the intelligence types and learning styles had a moderate positive correlation. 
Table 5. Multiple intelligences types of the students according to gender

\begin{tabular}{lccccccc}
\hline Types of Intelligence & Gender & $\mathrm{N}$ & $\mathrm{X}$ & $\mathrm{SS}$ & $\mathrm{t}$ & $\mathrm{Df}$ & $\mathrm{p}$ \\
\hline \multirow{2}{*}{ Verbal Intelligence } & Female & 45 & 3.9333 & .80904 & 2.551 & 86 & .013 \\
& Male & 43 & 3.4884 & .82728 & 2.549 & 85.601 & $\mathrm{p}<0.05$ \\
& Female & 45 & 3.8444 & .82450 & .401 & 86 & .689 \\
Logical Intelligence & Male & 43 & 3.7674 & .97192 & .400 & 82.421 & $\mathrm{p}>0.05$ \\
Visual Intelligence & Female & 45 & 4.1778 & .74739 & 1.757 & 86 & .083 \\
& Male & 43 & 3.8837 & .82258 & 1.753 & 84.316 & $\mathrm{p}>0.05$ \\
Musical Intelligence & Female & 45 & 3.9333 & .86340 & .555 & 86 & .58 \\
& Male & 43 & 3.8372 & .75373 & .557 & 85.318 & $\mathrm{p}>0.05$ \\
Kinesthetic Intelligence & Female & 45 & 4.0667 & .78044 & 1.763 & 86 & .081 \\
Interpersonal Intelligence & Male & 43 & 3.7674 & .81174 & 1.761 & 85.380 & $\mathrm{p}>0.05$ \\
Intrapersonal Intelligence & Female & 45 & 3.7333 & .83666 & .325 & 86 & .746 \\
& Male & 43 & 3.6744 & .86523 & .324 & 85.460 & $\mathrm{p}>0.05$ \\
Naturalistic Intelligence & Female & 45 & 3.8000 & .75679 & 1.045 & 86 & .299 \\
& Male & 43 & 3.6279 & .78750 & 1.044 & 85.373 & $\mathrm{p}>0.05$ \\
\hline
\end{tabular}

As shown in the table 6, Verbal intelligence is related to visual, tactile, auditory, and kinesthetic learning types. Logical intelligence is related to visual, tactile, auditory, and kinesthetic learning types. Visual Intelligence is related to visual, tactile, auditory, and kinesthetic learning types.

Table 6. The Correlation between multiple intelligence type of the students and learning styles of the students

\begin{tabular}{|c|c|c|c|c|c|c|c|}
\hline & & Visual & Tactile & Auditory & Group & Kinesthetic & Individual \\
\hline \multirow{3}{*}{$\begin{array}{l}\text { Verbal } \\
\text { Intelligence }\end{array}$} & Pearson Correlation & $.366^{* *}$ & $.421^{* *}$ & $.239^{*}$ & -.043 & $.305^{* *}$ & .102 \\
\hline & Sig. (2-tailed) & .000 & .000 & .025 & .692 & .004 & .343 \\
\hline & $\mathrm{N}$ & 88 & 88 & 88 & 88 & 88 & 88 \\
\hline \multirow{3}{*}{$\begin{array}{l}\text { Logical } \\
\text { Intelligence }\end{array}$} & Pearson Correlation & $.323^{* *}$ & $.443^{* *}$ & $.230^{*}$ & -.027 & $.330^{* *}$ & .157 \\
\hline & Sig. (2-tailed) & .002 & .000 & .031 & .804 & .002 & .144 \\
\hline & $\mathrm{N}$ & 88 & 88 & 88 & 88 & 88 & 88 \\
\hline \multirow{3}{*}{$\begin{array}{l}\text { Visual } \\
\text { Intelligence }\end{array}$} & Pearson Correlation & $.258^{*}$ & $.364^{* *}$ & $.442^{* *}$ & -.041 & $.428^{* *}$ & .204 \\
\hline & Sig. (2-tailed) & .015 & .000 & .000 & .705 & .000 & .057 \\
\hline & $\mathrm{N}$ & 88 & 88 & 88 & 88 & 88 & 88 \\
\hline \multirow{3}{*}{$\begin{array}{l}\text { Musical } \\
\text { Intelligence }\end{array}$} & Pearson Correlation & .174 & $.382^{* *}$ & $.259^{*}$ & -.018 & .205 & .158 \\
\hline & Sig. (2-tailed) & .106 & .000 & .015 & .868 & .055 & .141 \\
\hline & $\mathrm{N}$ & 88 & 88 & 88 & 88 & 88 & 88 \\
\hline \multirow{3}{*}{$\begin{array}{l}\text { Kinesthetic } \\
\text { Intelligence }\end{array}$} & Pearson Correlation & $.281^{* *}$ & $.437^{* *}$ & $.353^{* *}$ & .118 & $.386^{* * *}$ & $.211^{*}$ \\
\hline & Sig. (2-tailed) & .008 & .000 & .001 & .274 & .000 & .049 \\
\hline & $\mathrm{N}$ & 88 & 88 & 88 & 88 & 88 & 88 \\
\hline \multirow{3}{*}{$\begin{array}{l}\text { Interpersonal } \\
\text { Intelligence }\end{array}$} & Pearson Correlation & $.270^{*}$ & $.342^{* *}$ & $.270^{*}$ & .193 & $.346^{* *}$ & .094 \\
\hline & Sig. (2-tailed) & .011 & .001 & .011 & .072 & .001 & .386 \\
\hline & $\mathrm{N}$ & 88 & 88 & 88 & 88 & 88 & 88 \\
\hline \multirow{3}{*}{$\begin{array}{l}\text { Intrapersonal } \\
\text { Intelligence }\end{array}$} & Pearson Correlation & $.277^{* *}$ & $.383^{* *}$ & .108 & -.076 & .181 & .192 \\
\hline & Sig. (2-tailed) & .009 & .000 & .315 & .480 & .092 & .073 \\
\hline & $\mathrm{N}$ & 88 & 88 & 88 & 88 & 88 & 88 \\
\hline \multirow{3}{*}{$\begin{array}{l}\text { Naturalistic } \\
\text { Intelligence }\end{array}$} & Pearson Correlation & .195 & $.305^{* *}$ & $.263^{*}$ & -.161 & .181 & .182 \\
\hline & Sig. (2-tailed) & .069 & .004 & .013 & .134 & .091 & .089 \\
\hline & $\mathrm{N}$ & 88 & 88 & 88 & 88 & 88 & 88 \\
\hline
\end{tabular}

\section{Discussion}

The current study aimed to determine the relationship between male and female students' multiple intelligence types. The analyses showed that females preferred a higher degree of Tactile and Kinesthetic learning style type when compared to male participants. Similarly, Tabanlıoglu (2003) found a statistically significant gender difference in the preference of the tactile learning styles category between females and males.

In another context, a parallel finding was observed in Cheng and Banya's (1998) study. The participants in their study preferred the perceptual learning styles of Auditory, Tactile, and Individual learning. The findings of the study are in line with the results stated by Cheng and Banya, except for the individual learning. This finding shows that learners 
need to be aware of their thinking and analyze what they think and feel about learning. Identifying children's learning style is mostly permanent for each person, individuals can develop into a different style when they grow up. Teachers can influence the learners and help them develop their awareness on language learning and think about their way of learning by introducing some learning strategies.

In the present study, it was found that Naturalistic, Visual and Kinesthetic intelligence types received the highest score. It can be interpreted that the participants of the study lived in a village, and they were interested in nature very much. When the multiple intelligences types of male and female students was calculated a significant difference between the groups was not observed. Similar results were observed in Sarıcaoğlu and Arıkan's study (2009). They stated that there was not a relationship between learners' intelligence types and their genders. However, there was a positive relationship between gender and linguistic intelligence. This finding is similar to Saricaoglu and Arikan's study (2009), who found no relationship between students' gender and their intelligence types, except for the relationship between gender and linguistic intelligence that was positive.

However, in some other contexts multiple intelligences types of male and female students showed differences. In Furnham and Buchanan's study (2005) women tend to provide lower estimates of general, mathematical, and spatial ability, but higher estimates of interpersonal and intrapersonal intelligence than men. Similarly, in a study carried out by Nasser et al. (2008) Indian and Lebanese male learners' scores in Bodily-kinaesthetic intelligence were higher than those of females. However, females got better scores in Verbal-linguistic and intrapersonal intelligences.

For the third research question, it was revealed that most of the intelligence type and learning styles had a moderate positive correlation. This result was parallel with Panahandeh et al. (2015)'s study. In the study, some positive relationship between learning styles and intelligences in terms of gender and intelligences types, especially, were found.

The obtained results reported that there are some significant positive relationships between learning styles and combination of intelligences in general and types of intelligences in particular. Also Ahanbor and Sadighi (2014) founded that that there is statistically significant relationship between male and female students learning styles and multiple intelligences. This implies that multiple intelligences have a significant effect on learning styles of the students.

\section{Conclusion}

In this study the relationship between multiple intelligences types and learning styles were investigated. The results showed that the students had almost all these types of learning styles. Mostly they were found to be tactile and auditory learners, and three intelligence groups: Naturalistic, Visual and Kinesthetic intelligences types received the highest score. The participants of the study were adolescents and they lived in a village. For these reasons, the results were expected to be found.

Having identified their learning styles and being aware of the ways with which they can be more successful in their language learning journey, it is hoped that students will be familiar with their strengths and weaknesses, which will help them become more proficient language learners.

Most significantly, students should be aware of their weak and strong points in terms of learning practices. Thus, they have some opportunities to find correct styles to compensate for their weaknesses and develop their strengths, and make use of them. This can also allow them to develop self-confidence, self-respect, self-regulation, etc. and positive attitude toward learning. They will probably be more satisfied and relieved when they detect the reason of their learning problems.

\section{Recommendations}

This study gives a perspective on future implications of being aware of multiple intelligences and learning styles on designing lessons, materials, and learning environment. Teachers can take steps to improve their students' learning styles and intelligences through different techniques. They can, for instance, employ easier tasks and practices so that students can be more satisfied with their educational attainment. Moreover, they can plan and deliver a lot of different activities so that a large number of students with varying learning styles and intelligences can benefit from the instruction they receive. Yet it was a small scale study due to the school conditions and the number of students. It is recommended that further studies with large number of students may be carried out.

\section{References}

Ahanbor, Z., \& Sadighi, F. (2014). The relationship between multiple intelligences, learning styles and gender. Modern Journal of Language Teaching Methods, 4(1), 176-184.

Ali, A., \& Rajalakshmi, M. S. (2016). A concept paper on the importance of introducing parents to the multiple intelligences concept to help understand their child's learning styles. Indian Journal of Health and Wellbeing, 7(8), 837-840.

Armstrong, T. (2000). Multiple Intelligences in the Classroom, (2 ${ }^{\text {nd }}$ ed.). Alexandria, Virginia USA: Association for 
Supervision and Curriculum Development.

Armstrong, T. (2009). Multiple Intelligences in the classroom. Alexandria, VA: Association for Supervision and Curriculum Development.

Brown, H. D. (2000). Principles of language teaching and learning, (4th ed.). White Plains, NY: Longman.

Cheng, M. H., \& Banya, K. (1998). Bridging the gap between teaching and learning styles. In J. Reid (Ed.). Understanding learning styles in the second language classroom (pp. 80-84). USA: Prentice Hall Regents.

Dörnyei, Z. (2007). Research Methods in Applied Linguistics. Spain: Oxford.

Furnham, A., \& Buchanan, T. (2005). Personality, Gender and Self-Perceived Intelligence. Personality and Individual Differences, 39, 543-555. https://doi.org/10.1016/j.paid.2005.02.011

Gardner, H. (1983). Frames of mind: The theory of multiple intelligences. New York: Basic Books.

Gardner, H. (1993). Multiple Intelligence: Theory in practice. New York: Basic Books.

Gardner, H. (1999). Intelligence reframed: Multiple intelligences for the 21 st century. New York: Basic Books.

Hsu, C. W., \& Chen, S. C. (2016). A study of EFL college students' learning styles and learning strategies. Journal of Modern Education Review, January, 6(1), 1-9, USA. Retrieved from http://www.academicstar.us/issueshow.asp?daid=1464

Luengo-Cervera, E. (2015). Learning styles and multiple intelligences in the teaching-learning of Spanish as a foreign language. Enseñanza and Teaching, 33, 2-2015, 79-103. https://doi.org/10.14201/et201533279103

MacKeracher, D. (2004). Making sense of adult learning, (2nd ed.). Canada: University of Toronto Press Incorporated.

Mackey, A., \& Gass, S. M. (2005). Second Language Research: Methodology and Design. USA: Lawrence Erlbaum Assocites, Publishers.

Nasser, R., Singhal, S., \& Abouchedid, K. (2008). Gender differences on self-estimates of Multiple Intelligences: A comparison between Indian and Lebanese Youths. Journal of Social Science, 16(3), 235-243. https://doi.org/10.1080/09718923.2008.11892624

Panahandeh, E., Khoshkhoonejad, A., Mansourzadeh, N., \& Heidari, F. (2015). On the relationship between Iranian EFL learners' multiple intelligences and their learning styles. Theory and Practice in Language Studies, 5(4), 784-791, Retrieved from http://dx.doi.org/10.17507/tpls.0504.14

Reid, J. (1995). Learning Styles in the ESL/EFL Classroom. Boston: Heinle \& Heinle.

Sarıcaoğlu, A., \& Arıkan, A. (2009). A Study of multiple intelligences, foreign language success and some selected variables. International Journal of Educational Researchers, 1(1), 22-36.

Tabanlıoglu, S. (2003). The relationship between warning styles and language learning strategies of pre-intermediate EAP student. (Unpublished Master's Thesis). Middle East Technical University, Turkey.

Teele, S. (2000). Rainbows of intelligence: Exploring how students learn. California Corwin Press, INC.

Tekiner, A. (2005). The relationship between perceptional and social learning styles and multiple intelligences and their effects on English proficiency of Turkish young adults learning English as a foreign language. (Unpublished Master Thesis). The Middle East Technical University.

Tomakin, E. (2012). İlköğretim bölümü matematik, fen bilgisi, sosyal bilgiler ve sınıf öğretmenliği öğrencilerinin İngilizce öğrenme yöntemleri. Atatürk Üniversitesi Sosyal Bilimler Enstitüsü Dergisi, 16(3), 231-274.

Tsai, M. Y. (2016). Research on Multiple Intelligences of Junior High School Students with Different Background Variables. Journal of Modern Education Review, 6(1), 10-18.

https://doi.org/10.15341/jmer(2155-7993)/01.06.2016/002

\section{Copyrights}

Copyright for this article is retained by the author(s), with first publication rights granted to the journal.

This is an open-access article distributed under the terms and conditions of the Creative Commons Attribution license which permits unrestricted use, distribution, and reproduction in any medium, provided the original work is properly cited. 